\title{
PENGARUH PENDAPATAN ASLI DAERAH, DANA ALOKASI UMUM, DANA ALOKASI KHUSUS, DANA BAGI HASIL DAN SISA LEBIH PERHITUNGAN ANGGARAN TERHADAP BELANJA MODAL
}

\author{
Yuliani $^{1}$, Dirvi Surya Abbas ${ }^{2}$, Mohamad Zulman Hakim ${ }^{3}$ \\ Universitas Muhammadiyah Tangerang ${ }^{1,2,3}$ \\ Koresponden Email : yulianie1978@gmail.com
}

\begin{abstract}
Abstrak : Tujuan penelitian ini adalah untuk mengetahui pengaruh Pendapatan Asli Daerah (PAD), Dana Alokasi Umum (DAU), Dana Alokasi Khusus (DAK), Dana Bagi Hasil (DBH) dan Sisa Lebih Perhitungan Anggaran (SiLPA) Terhadap Belanja Modal Pemerintah Kabupaten/Kota di Provinsi Jambi. Populasi dalam penelitian adalah laporan realisasi keuangan 11 Pemerintah Kabupaten/Kota yang ada di Provinsi Jambi Periode 2014-2018. Pengambilan sampel menggunakan teknik purposive sampling yaitu pemilihan sampel dengan kriteria tertentu, sehingga didapat sampel dalam penelitian ini sebanyak 5 laporan keuangan. Hasil penelitian ini menunjukkan adanya pengaruh secara simultan antara Pendapatan Asli Daerah (PAD), Dana Alokasi Umum (DAU), Dana Alokasi Khusus (DAK), Dana Bagi Hasil (DBH) dan Sisa Lebih Perhitungan Anggaran terhadap Belanja Modal.
\end{abstract}

Kata Kunci : Belanja Modal, PAD, DAU, DAK, DBH, SiLPA

Dalam rangka pelaksanaan Otonomi Daerah, agar pemerintah dapat melaksanakan fungsinya secara efektif, maka pemerintah daerah harus didukung sumber-sumber pembiayaan yang memadai baik yang berasal dari Dana Perimbangan yang terdiri dari Pendapatan Asli Daerah (PAD), Dana Alokasi Umum (DAU), Dana Alokasi Khusus (DAK), Dana Bagi Hasil $(\mathrm{DBH})$ maupun lain-lain dari Penerimaan Daerah yang sah.

Belanja modal menurut Peraturan Menteri Dalam Negeri Nomor 21 Tahun 2011 Pasal 53, adalah belanja yang digunakan untuk pengeluaran yang dilakukan dalam rangka pembelian/pengadaan atau pembangunan aset tetap berwujud yang mempunyai nilai manfaat lebih dari 12 (dua belas) bulan untuk digunakan dalam kegiatan pemerintahan.

Menurut UU No 32 Tahun 2004, Pendapatan Asli Daerah (PAD) yaitu penerimaan yang berasal dari hasil pajak daerah, pajak retribsi daerah dan hasil pengelolaan kekayaan daerah yang dipisahkan dan lainlain PAD yang sah atau hak Pemerintah Daerah yang diakui sebagai penambahan nilai kekayaan bersih daerah.

Dana perimbangan berupa Dana Alokasi Umum (DAU) adalah dana yang berasal dari APBN yang disalurkan ke pemerintah daerah sebagai pemerataan keuangan daerah dan untuk mengatasi kesenjangan antar daerah.

Dana Alokasi Khusus (DAK) adalah dana perimbangan yang menjadi bagian sumber pendapatan yang diatur dalam Peraturan Pemerintah (PP) 
PROSIDING SEMINAR NASIONAL EKONOMI DAN BISNIS 2021

UNIVERSITAS MUHAMMADIYAH JEMBER

dalam bentuk realisasi belanja daerah. DAK bersumber dari dana APBN untuk membantu membiayai program khusus didaerah, untuk membiayai kebutuhan sarana dan prasarana pelayanan dasar masyarakat yang belum mencapai standar tertentu.

Dana Bagi Hasil adalah dana yang bersumber dari pendapatan APBN yang dialokasikan kepada daerah berdasarkan angka persentase tertentu untuk mendanai kebutuhan daerah dalam rangka pelaksanaan desentralisasi. DBH dialokasikan dengan tujuan untuk memperbaiki keseimbangan vertikal antara pusat dan daerah dengan memperhatikan potensi daerah penghasil.

Sisa Lebih Perhitungan Anggaran (SiLPA) menurut Peraturan Pemerintah Nomor 58 Tahun 2005 adalah selisih lebih realisasi penerimaan dan pengeluaran anggaran dalam satu periode anggaran. Jika belanja daerah pada tahun tertentu rendah maka otomatis SiLPA ditahun tersebut akan besar.

Tujuan dari Penelitian ini adalah untuk membuktikan secara empiris penelitian sehingga mampu menganalisis dan menjelaskan:

6. Pengaruh Pendapatan Asli Daerah (PAD) berpengaruh terhadap pengalokasian belanja modal.

7. Pengaruh Dana Alokasi Umum (DAU) berpengaruh terhadap pengalokasian belanja modal.

8. Pengaruh Dana Alokasi Khusus (DAK) berpengaruh terhadap pengalokasian belanja modal.

9. Pengaruh Dana Bagi Hasil (DBH) berpengaruh terhadap pengalokasian belanja modal.

10. Pengaruh Sisa Lebih Perhitungan Anggaran (SiLPA) berpengaruh terhadap pengalokasian belanja modal.

\section{METODE}

Dalam penelitian ini metode pengumpulan sampel menggunakan metode Proporsive sampling (kriteria sampel), yaitu kriteria sesuai dengan variabel $Y$ dan $X$ dengan cara mengumpulkan setiap sampel kabupaten dan kota yang diperlukan dalam penelitian ini, kemudian sampel kabupaten dan kota tersebut dipelajari, dipahami, dan dilanjutkan dengan proses pencatatan dan perhitungan terhadap data- data yang bersifat relevan terhadap permasalahan yang diteliti, sumber data yang digunakan pada penelitian ini diperoleh dengan cara mengunjungi situs (djpk.kemenkeu.go.id), dan berpatokan pada laporan realisasi anggaran APBD Tahun 2014 dan 2018. 
PROSIDING SEMINAR NASIONAL EKONOMI DAN BISNIS 2021

\section{UNIVERSITAS MUHAMMADIYAH JEMBER}

\section{HASIL}

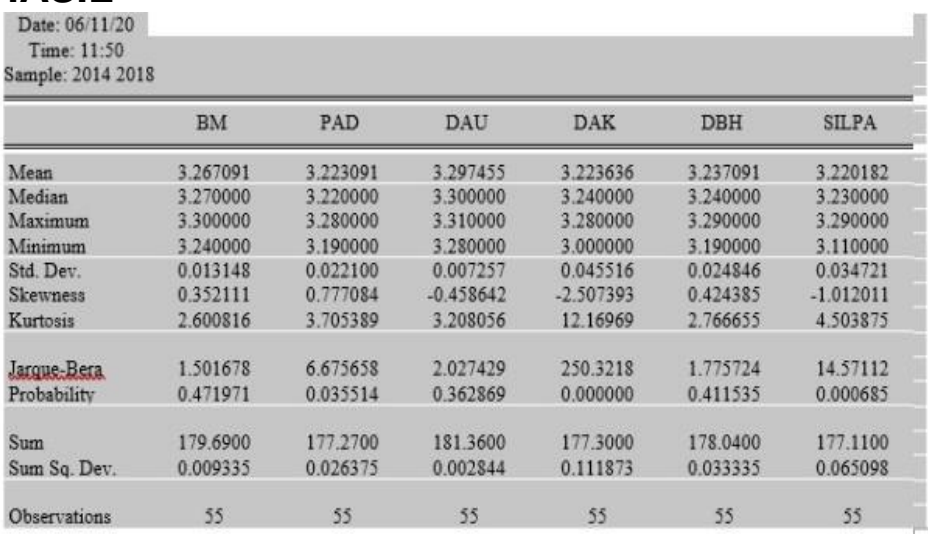

\begin{tabular}{|c|c|c|c|c|}
\hline \multicolumn{5}{|c|}{$\begin{array}{l}\text { Dependent Variable: BM } \\
\text { Method: Panel Least Squares } \\
\text { Date: } 06 / 11 / 20 \text { Time: } 11: 53 \\
\text { Sample: } 20142018 \\
\text { Periods included: } 5 \\
\text { Cross-sections included: } 11 \\
\text { Total panel (balanced) observations: } 55\end{array}$} \\
\hline Variable & Coefficient & Std. Error & $\mathrm{t}$-Statistic & Prob. \\
\hline $\mathrm{C}$ & -1.295761 & 0.694130 & -1.866742 & 0.0679 \\
\hline PAD & -0.046096 & 0.064802 & -0.711335 & 0.4802 \\
\hline $\mathrm{DAU}$ & 0.894674 & 0.222079 & 4.028622 & 0.0002 \\
\hline DAK & 0.003511 & 0.031857 & 0.110222 & 0.9127 \\
\hline $\mathrm{DBH}$ & 0.313779 & 0.050671 & 6.192460 & 0.0000 \\
\hline SILPA & 0.228008 & 0.035797 & 6.369564 & 0.0000 \\
\hline R-squared & 0.635568 & \multicolumn{2}{|c|}{ Mean dependent var } & 3.267091 \\
\hline Adjusted R-squared & 0.598381 & \multicolumn{2}{|c|}{ S.D. dependent var } & 0.013148 \\
\hline S.E. of regression & 0.008332 & \multicolumn{2}{|c|}{ Akaike info criterion } & -6.634723 \\
\hline Sum squared resid & 0.003402 & \multicolumn{2}{|c|}{ Schwarz criterion } & -6.415741 \\
\hline Log likelihood & 188.4549 & \multicolumn{2}{|c|}{ Hannan-Quinn criter. } & -6.550041 \\
\hline F-statistic & 17.09117 & \multirow{2}{*}{\multicolumn{2}{|c|}{ Durbin-Watson stat }} & 1.575716 \\
\hline Prob(F-statistic) & 0.000000 & & & \\
\hline
\end{tabular}


PROSIDING SEMINAR NASIONAL EKONOMI DAN BISNIS 2021

\section{UNIVERSITAS MUHAMMADIYAH JEMBER}

\begin{tabular}{|c|c|c|c|c|}
\hline $\begin{array}{l}\text { Dependent Variable: } \\
\text { Method: Panel Least } \\
\text { Date: } 06 / 11 / 20 \text { Tim } \\
\text { Sample: } 20142018 \\
\text { Periods included: } 5 \\
\text { Cross-sections includ } \\
\text { Total panel (balanced }\end{array}$ & $\begin{array}{l}\text { BM } \\
\text { Squares } \\
11: 59\end{array}$ & & & \\
\hline Variable & Coefficient & Std. Error & $\mathrm{t}$-Statistic & Prob. \\
\hline C & -0.582451 & 0.889939 & -0.654484 & 0.5166 \\
\hline PAD & -0.140859 & 0.132181 & -1.065646 & 0.2931 \\
\hline DAU & 1.013374 & 0.247590 & 4.092943 & 0.0002 \\
\hline DAK & -0.005570 & 0.026327 & -0.211557 & 0.8336 \\
\hline DBH & 0.118163 & 0.085521 & 1.381688 & 0.1749 \\
\hline SILPA & 0.185529 & 0.031524 & 5.885424 & 0.0000 \\
\hline \multicolumn{5}{|c|}{ Effects Specification } \\
\hline \multicolumn{5}{|c|}{ Cross-section fixed (dummy variables) } \\
\hline R-squared & 0.850900 & \multicolumn{2}{|c|}{ Mean dependent var } & 3.267091 \\
\hline Adjusted R-squared & 0.793553 & \multicolumn{2}{|c|}{ S.D. dependent var } & 0.013148 \\
\hline S.E. of regression & 0.005974 & \multicolumn{2}{|c|}{ Akaike info criterion } & -7.164806 \\
\hline Sum squared resid & 0.001392 & \multicolumn{2}{|c|}{ Schwarz criterion } & -6.580854 \\
\hline Log likelihood & 213.0322 & \multicolumn{2}{|c|}{ Hannan-Quinn criter. } & -6.938987 \\
\hline F-statistic & 14.83790 & \multicolumn{2}{|c|}{ Durbin-Watson stat } & 2.871992 \\
\hline Prob(F-statistic) & 0.000000 & & & \\
\hline
\end{tabular}

Gambar 3. Hasil Uji FEM

Dependent Variable: BM

Method: Panel EGLS (Cross-section random effects)

Date: 06/11/20 Time: 12:01

Sample: 20142018

Periods included: 5

Crosi-sactions included: 11

Total panel (balasced) observations: 55

Swamy and Arora estimator of component variances

\begin{tabular}{|c|c|c|c|c|}
\hline Variable & Coefficient & Std. Error & t-Statistic & Prob. \\
\hline C & -0.937704 & 0.744501 & -1.259506 & 0.2138 \\
\hline PAD & -0.061389 & 0.090530 & -0.678107 & 0.5009 \\
\hline DAU & 0.940281 & 0.225612 & 4.167695 & 0.0001 \\
\hline DAK & -0.004415 & 0.025156 & -0.175491 & 0.8614 \\
\hline DBH & 0.214237 & 0.066108 & 3.240717 & 0.0021 \\
\hline SILPA & 0.193420 & 0.030457 & 6.350569 & 0.0000 \\
\hline \multicolumn{5}{|c|}{ Effects Specification } \\
\hline & & & S.D. & Rho \\
\hline Cross-saction random & & & 0.007230 & 0.5943 \\
\hline Idiosyncratic random & & & 0.005974 & 0.4057 \\
\hline \multicolumn{5}{|c|}{ Weighted Statistics } \\
\hline R-squared & 0.544898 & \multirow{2}{*}{\multicolumn{2}{|c|}{$\begin{array}{l}\text { Mean dependent var } \\
\text { S.D. dependent var }\end{array}$}} & 1.132439 \\
\hline Adjusted R-squared & 0.498460 & & & 0.008385 \\
\hline S.E. of regression & 0.005938 & \multicolumn{2}{|c|}{ Sum squared resid } & 0.001728 \\
\hline F-statistic & 11.73366 & \multicolumn{2}{|c|}{ Durbin-Watson stat } & 2.577466 \\
\hline Prob(F-statistic) & 0.000000 & & & \\
\hline \multicolumn{5}{|c|}{ Unweighted Statisties } \\
\hline R-squared & 0.592409 & \multirow{2}{*}{\multicolumn{2}{|c|}{$\begin{array}{l}\text { Mean dependest var } \\
\text { Durbin-Watson stat }\end{array}$}} & 3.267091 \\
\hline Sum squared tesid. & 0.003805 & & & 1.170415 \\
\hline
\end{tabular}


PROSIDING SEMINAR NASIONAL EKONOMI DAN BISNIS 2021

\section{UNIVERSITAS MUHAMMADIYAH JEMBER}

Gambar 4. Hasil Uji REM

\begin{tabular}{|c|c|c|c|}
\hline \multicolumn{4}{|c|}{$\begin{array}{l}\text { Redumdant Fixed Effects Teats } \\
\text { Equation: Untitled }\end{array}$} \\
\hline \multicolumn{4}{|c|}{ Test cross-section fixed effects } \\
\hline Effects Test & Statistic & df & Prob. \\
\hline Crost-section F & 5.632393 & $(10,39)$ & 0.0000 \\
\hline Crost-section Chi-aquare & 49.154557 & 10 & 0.0000 \\
\hline
\end{tabular}

Gambar 5. Hasil Perhitungan Uji Chow

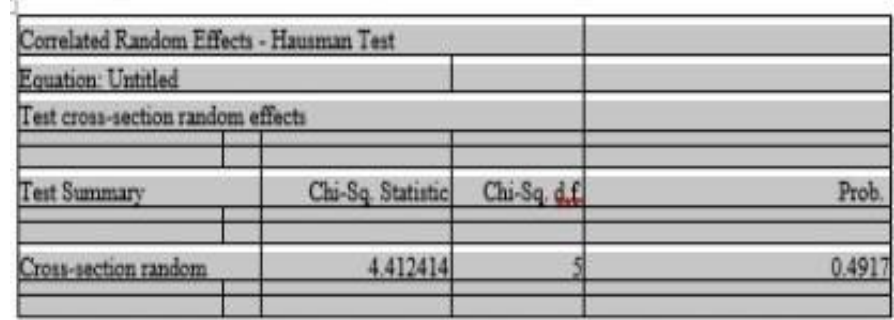

Gambar 6. Hasil Perhitungan Uji Hausman

\begin{tabular}{|c|c|c|c|}
\hline \multicolumn{4}{|c|}{ Lagrange Multiplier Tests for Random Effects } \\
\hline \multicolumn{4}{|c|}{$\begin{array}{l}\text { Null hypotheses: No effects } \\
\text { Alternative hypotheses: Two-sided (Breusch-Pagan) and one- } \\
\text { sided }\end{array}$} \\
\hline \multicolumn{4}{|c|}{ (2ll othen) alternatives } \\
\hline \multicolumn{4}{|c|}{ Teat Hypothesia } \\
\hline & Cross-section & Time & Both \\
\hline \multirow[t]{2}{*}{ Brousch-Pagan } & 17.05019 & 1.206855 & 18.25705 \\
\hline & $(0.0000)$ & $(0.2720)$ & 0.0000 \\
\hline \multirow[t]{2}{*}{ Honda } & 4.129188 & -1.098570 & 2.142971 \\
\hline & $(0.0000)$ & - & $(0.0161)$ \\
\hline \multirow[t]{2}{*}{ King-Wu } & 4.129188 & -1.098570 & 1.278683 \\
\hline & $(0.0000)$ & - & $(0.1005)$ \\
\hline Standardized Honda & 5.550667 & -0.793614 & -0.118076 \\
\hline \multirow{3}{*}{$\begin{array}{l}\text { Standardized King- } \\
\text { Wu }\end{array}$} & $(0.0000)$ & - & \\
\hline & 5.550667 & .0 .793614 & -0.973063 \\
\hline & $(0.0000)$ & - & \\
\hline \multirow[t]{2}{*}{ Sourierious, et al." } & -. & - & 17.05019 \\
\hline & & & $(<0.01)$ \\
\hline \multicolumn{4}{|c|}{ Mixed chi-square asymptotic critical values: } \\
\hline \multicolumn{4}{|c|}{$1 \% \quad 7.289$} \\
\hline $5 \%$ & 4.321 & & \\
\hline $10 \%$ & 2.952 & & \\
\hline
\end{tabular}

Gambar 7. Hasil Perhitungan Uji Multiplier 


\section{PROSIDING SEMINAR NASIONAL EKONOMI DAN BISNIS 2021 UNIVERSITAS MUHAMMADIYAH JEMBER}

\begin{tabular}{|c|l|c|c|}
\hline \hline \multicolumn{1}{|c|}{ Metode } & Pengujian & Hasil \\
\hline No & \multicolumn{1}{|c|}{ FEM } \\
\hline 1 & UjiChow & CEM vs FEM & REM \\
\hline 2 & UjiHausman & REM vs FEM & REM \\
\hline 3 & UjiLagrage Multiplier & CEM vs REM & REM \\
\hline
\end{tabular}

Tabel 1. Hasil Kesimpulan Uji

\begin{tabular}{ll}
\hline F-statistic & 11.73366 \\
Prob(F-statistic) & 0.000000 \\
\hline \hline
\end{tabular}

Gambar 8. Hasil Uji Kelayakan Model (Uji F) T.

\begin{tabular}{ll}
\hline \hline R-squared & 0.544898 \\
Adiusted R-squared & 0.498460
\end{tabular}

Gambar 9. Hasil Perhitungan koefisien Determinasi

\begin{tabular}{crrrr} 
Variable & Coefficient & Std. Error & t-Statistic & Prob. \\
\hline \hline C & -0.937704 & 0.744501 & -1.259506 & 0.2138 \\
PAD & -0.061389 & 0.090530 & -0.678107 & 0.5009 \\
DAU & 0.940281 & 0.225612 & 4.167695 & 0.0001 \\
DAK & -0.004415 & 0.025156 & -0.175491 & 0.8614 \\
DBH & 0.214237 & 0.066108 & 3.240717 & 0.0021 \\
SILPA & 0.193420 & 0.030457 & 6.350569 & 0.0000 \\
\hline \hline
\end{tabular}

Gambar 10. Hasil Perhitungan Uji T

Variabel Pendapatan Asli Daerah (X1) dalam pengujian ini tidak memiliki pengaruh terhadap Belanja Modal pada Provinsi Jambi, hal ini disebabkan karena PAD pada Pemerintah Kabupaten/Kota di Provinsi Jambi lebih banyak digunakan untuk membiayai belanja yang lain seperti belanja rutin/belanja operasional juga karena suatu daerah kurang dalam menggali potensi daerah yang dapat dimanfaatkan secara berkelanjutan. Hal ini juga dapat dilihat dari hasil perhitungan uji t statistic yaitu 0.678107 . 
PROSIDING SEMINAR NASIONAL EKONOMI DAN BISNIS 2021

UNIVERSITAS MUHAMMADIYAH JEMBER

Variabel Dana Alokasi Umum (X2) dalam pengujian ini memiliki pengaruh positif dan signifikan terhadap Belanja Modal. Hal ini menjelaskan bahwa Pemerintah Kabupaten/Kota pada Provinsi Jambi DAU yang besar dan dapat dilihat dari hasil uji t statistic 4.167695.

Variabel Dana Alokasi Khusus (X3) dalam pengujian ini tidak memiliki pengaruh terhadap Belanja Modal karena DAK yang diterima oleh Pemerintah Kabupaten/Kota pada Provinsi Jambi dan hal ini bisa dilihat dari hasil uji t statistik yang diperoleh sebesar -0.175491 .

Variabel Dana Bagi Hasil (X4) dalam pengujian ini memiliki pengaruh terhadap Belanja Modal. Hal ini menjelaskan bahwa Pemerintah Kabupaten/Kota pada Provinsi Jambi mendapatkan DBH yang besar dan dapat dilihat dari hasil uji t statistik yang diperoleh nilai 3.240717.

Variabel Sisa Lebih Perhitungan Anggaran (X5) dalam pengujian ini memiliki pengaruh terhadap Belanja Modal. Hal ini menjelaskan bahwa peranan SiLPA merupakan indikator efisiensi karena SiLPA akan terbentuk bila terjadi surplus pada APBD Pemerintah Kabupaten/Kota pada Provinsi Jambi dan SiLPA akan berpengaruh besar pada komposisi belanja daerah. Hal ini juga dapat dilihat dari hasil uji t statistik yang diperoleh nilai 6.350569 .

Teori stewardship menjelaskan mengenai situasi manajemen tidaklah termotivasi oleh tujuan-tujuan individu melainkan lebih ditujukan pada sasaran hasil utama mereka untuk kepentingan organisasi (Donaldson, 1989 dan Davis, 1991). Teori ini mengambarkan tentang adanya hubungan yang kuat antara kepuasan dan kesuksesan organisasi. Pemerintah selaku steward dengan fungsi pengelola sumber daya dan rakyat selaku principal pemilik sumber daya. Terjadi kesepakatan yang terjalin antara pemerintah (steward) dan rakyat (principal) berdasarkan kepercayaan, kolektif sesuai tujuan organisasi. Organisasi sektor public memiliki tujuan memberikan pelayanan kepada public dan dapat di pertanggungjawabkan kepada masyarakat (publik). Sehingga dapat diterapkan dalam model kasus organisasi sektor publik dengan teori stewardship.

Dalam Penelitian ini penulis hanya membahas mengenai Pendapatan Asli Daerah (PAD), Dana Alokasi Umum (DAU), Dana Alokasi Khusus (DAK), Dana Bagi Hasil (DBH), Sisa Lebih Perhitungan Anggaran (SiLPA) Terhadap belanja modal pada Pemerintah Kabupaten/Kota pada Provinsi Jambi periode laporan keuangan tahun 2014 sampai dengan 2018.

\section{KESIMPULAN}


PROSIDING SEMINAR NASIONAL EKONOMI DAN BISNIS 2021

UNIVERSITAS MUHAMMADIYAH JEMBER

Berdasarkan hasil analisis data yang telah dilakukan dan pembahasan mengenai hasil dari penelitian, maka keksimpulan dalam penelitian yang dilakukan ini adalah sebagai berikut :

1. Variabel Pendapatan Asli Daerah (X1) tidak berpengaruh terhadap Belanja Modal.

2. Variabel Dana Alokasi Umum (X2) dalam pengujian ini berpengaruh positif terhadap Belanja Modal.

3. Variabel Dana Alokasi Khusus (X3) tidak berpengaruh terhadap Belanja Modal.

4. Variabel Dana Bagi Hasil (X4) berpengaruh positif terhadap Belanja Modal.

5. Variabel Sisa Lebih Perhitungan Anggaran (X5) berpengaruh positif terhadap Belanja Modal.

\section{DAFTAR PUSTAKA}

Aditya, Dina Mei Eka, \& Maryono. (2018). Pengaruh Pendapatan Asli Daerah, Dana Alokasi Umum, Dana Alokasi Khusus, Dana Bagi Hasil Terhadap Belanja Modal (Studi Pada Provinsi/Wilayah Kalimantan dan Sulawesi).

Eksandy, A., Hakim, M. Z., \& Ekawati. (2015). Pengaruh Pendapatan Asli Daerah, Dana Alokasi Umum Dan Dana ALokasi Khusus Terhadap Belanja Modal (Pada Pemerintah Provinsi Banten Periode 20112015).

Kusumawardani, I. (2018). Pengaruh PAD, DAU, DAK, SiLPA Dan Pertumbuhan Ekonomi Trehadap Belanja Modal DI KAbupaten/Kota Jawa Tengah Tahun 2010-2015.

Ngestiningsih, L. A. (2019). Pengaruh Pendapatan Asli Daerah (PAD), Dana Perimbangan dan Sisa Lebih Pembiayaan( SiLPA) Terhadap Belanja Modal ( Studi Empiris Pada Pemerintah Kabupaten / Kota di Provinsi Jawa Tengah Tahun 2014-2016).

Noor Aini Arifah, H. (2019). Dan Kinerja Keuangan Terhadap Belanja Modal Di Kabupaten / Kota Provinsi Jawa Tengah Tahun 2015-2017. 8(2013)

Novianto, R., \& Hanafiah, R. (2015). Pengaruh Pendapatan Asli Daerah, Dana Perimbangan Dan Kinerja Keuangan Terhadap Alokasi Belanja Modal Pada Pemerintah Kabupaten / Kota Di Provinsi Kalimatan Barat.

Prasetya, I. (2017). Pengaruh Pendapatan Asli Daerah, Dana Alokasi Umum, Dana Alokasi Khusus, Dna Bagi Hasil dan Belanja Pegawai Terhadap Pengalokasian Anggaran Belanja Modal.

Susanti, S., \& Fahlevi, H. (2016). Pengaruh Pendapatan Asli Daerah, Dana Alokasi Umum, dan Dana Bagi Hasil Terhadap Belanja Modal (Studi Pada Kabupaten/Kota di Wilayah Aceh). 
PROSIDING SEMINAR NASIONAL EKONOMI DAN BISNIS 2021

\section{UNIVERSITAS MUHAMMADIYAH JEMBER}

Vanesha, V. T., Rahmadi, S., \& Parmadi, P. (2019). Pengaruh pendapatan asli daerah, dana alokasi umum dan dana alokasi khusus terhadap belanja modal pada kabupaten/kota di Provinsi Jambi. 